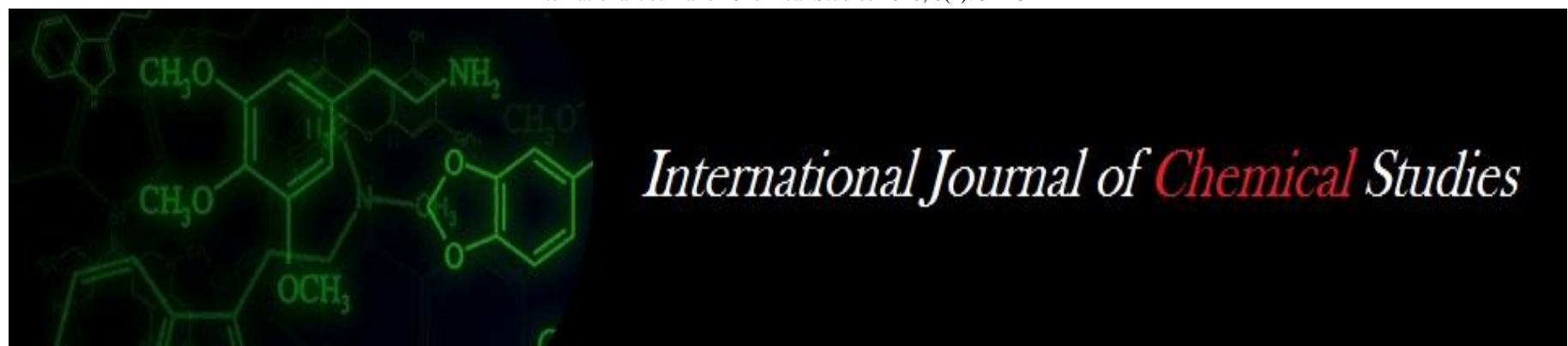

P-ISSN: 2349-8528

E-ISSN: 2321-4902

www.chemijournal.com

IJCS 2020; 8(2): 314-322

(C) 2020 IJCS

Received: 10-01-2020

Accepted: 14-02-2020

\section{Ravi Kumar}

Department of Processing and

Food Engineering, CCS Haryana

Agricultural University, Hisar,

Haryana, India

Reetika

Department of Horticulture, CCS

Haryana Agricultural

University, Hisar, Haryana,

India

\section{Sapna Birania}

Department of Processing and

Food Engineering, CCS Haryana

Agricultural University, Hisar,

Haryana, India

\section{Charan Singh}

Department of Processing and

Food Engineering, CCS Haryana

Agricultural University, Hisar

Haryana, India

\section{Ugarsain}

Department of Soil and Water

Engineering, CCS Haryana

Agricultural University, Hisar,

Haryana, India

Neha

Department of Food and

Nutrition CCS Haryana

Agricultural University, Hisar,

Haryana, India

\section{Nitin Kumar}

Department of Processing and

Food Engineering, CCS Haryana

Agricultural University, Hisar,

Haryana, India
Corresponding Author:

\section{Reetika}

Department of Horticulture, CCS

Haryana Agricultural

University, Hisar, Haryana,

India

\section{Current status of horticulture in Haryana: Constraints and future prospects}

\author{
Ravi Kumar, Reetika, Sapna Birania, Charan Singh, Ugarsain, Neha and \\ Nitin Kumar
}

DOI: https://doi.org/10.22271/chemi.2020.v8.i2e.8786

\begin{abstract}
Agriculture sector plays a remarkable role in the economy of Haryana as it is chiefly an agrarian economy. More than $50 \%$ of the number of residents of the state is straightforwardly or in a roundabout way relies upon this division for their livelihood. Ideal agro-climatic conditions give great chance to the advancement of horticultural crops in the state. The objective of the study is to examine the special problems in horticultural crops in Haryana. There is a need and potential for crop diversification by developing the horticulture sector in the state. In the present study, an attempt has been made to study the status and constraints of protected cultivation and agro processing industries because to minimize the post-harvest losses, a comprehensive strategy which incorporates advancement of physical, functional and market infrastructure along with provision of single window system, tax rebate and export subsidy need to develop to boost agro processing in the state.
\end{abstract}

Keywords: Horticulture, protected cultivation, agro processing, post-harvest losses

\section{Introduction}

Haryana has a very fertile land and is called the 'Green land of India'. Total geographical area of Haryana is $43,71,000$ ha, out of which cropped area is $64,71,000$ ha. Nearly $80 \%$ of the total area is under cultivation, from that about $84 \%$ area is irrigated with $182 \%$ cropping intensity. Area under Horticultural crops is 5,28,940 ha which covers around $8.17 \%$ of the cropped area (Anonymous, 2017) ${ }^{[3]}$. Agriculture sector plays a noteworthy role in the economy of Haryana as it is chiefly an agrarian economy. More than 50 percent of the population of the state is directly or indirectly depends on this sector for their livelihood.

Currently fruits, vegetables, flowers and mushrooms, are significant horticultural crops developed in Haryana which represents for $6.4 \%$ of the total crop region in the state. Every effort is being made to achieve the target of $10 \%$. The state has small acreage under spices, medicinal and aromatic plants also. Haryana is now a leading mushroom producing state in the country. Subsequently marketing of mushroom alongside different sorts of therapeutic mushrooms ought to be the future approach. Development of aromatic plants is additionally expanding because of more significant earnings.

Changes in efficiency of significant horticultural crops over years are the impressions of good accomplishments up until this point. Under Horticulture Mission, endeavors will be made to expand it further. Each action will be made, utilizing front line innovation to make horticulture a worthwhile recommendation for the farmers in Haryana. More emphasis will be placed on increased acreage under hybrids and adoption of protected cultivation in larger areas with soft loan facility along with improved agro techniques (Anonymous, 2015) ${ }^{[2]}$. Innovative work endeavors will be reoriented to address the issues and desires for farmers. Production of value seeds and planting materials will get high importance. New opportunities will be explored on arid horticulture technology including agro forestry systems and develop functional foods and nutraceuticals using fruits and vegetables and indigenous flora. Perennial fruits for agro horticulture and tree species for agro forestry, using micro irrigation, shall be promoted including raising of bees as pollinators for ensuring higher production of many crops. 


\section{Haryana horticulture scenario}

Haryana bears 4.42 million ha area out of which 3.55 million ha is the only cultivable area. The total net irrigated area of the state was 3073 thousand ha in the year 2013-14, out of which, 1879 thousand ha area was being irrigated by wells and the rest area through canals (Anonymous, 2014) ${ }^{[1]}$. In the year 2015-16, the number of marginal holdings (below 1 ha) were 803 thousand with an area of 392 thousand ha, number of small holdings (1-2 ha) were 314 thousand with an area of 460 thousand ha while total number of holdings were 1628 thousands along with 3609 thousand ha area (Anonymous, 2018) ${ }^{[4]}$.

Different new plans were propelled during the most recent decade. The activities were taken by the government to establish horticulture in Haryana. A significant change in climate on a global scale will impact horticulture and agriculture as a whole; consequently, affect the world's food supply. Climatic changeability is not really hurtful; the issues emerge from outrageous occasions that are hard to anticipate. Increasingly erratic precipitation designs and changeable high temperature spells subsequently decrease crop productivity. Horticultural crops are generally sensitive to environmental extremes and thus high temperatures and limited soil moisture are the major causes of low yields and will be further magnified by climate change. Protected cultivation is very helpful to provide the favorable condition that horticulture cultivation is needed. A poly house is a type of protected structure in which plants are grown under a controlled condition. These structures range in size from small sheds to industrial-sized buildings. The hi-tech production of horticultural crops under protected conditions is the recent development in this field. Protected cultivation is capital intensive and has capacity not only to increase the productivity of vegetables by many folds but also improves the quality of horticultural produce by successful production of virus free cultivation with insect proof net houses even on a commercial scale (Singh et al., 2007) [27]. Thus, protected cultivation of Horticultural crops may give a boost to horticulture production in the state on the one hand and also can be helpful in diversifying Haryana agriculture on the other. Diversification towards horticultural crops in Haryana requires considerable changes in form of favorable price regime, technological up gradation for increasing the productivity of these crops, financial support, and more upgraded and appropriate infrastructure facilities (Kumar and Akshu, 2018) ${ }^{[18]}$.

\section{Indian Horticulture Scenario}

India has seen increment in horticulture production in the course of the most recent couple of years. Critical advancement has been made in zone development bringing about higher production. India has witnessed increase in horticulture production over the last few years. Significant progress has been made in area expansion resulting in higher production. In the course of the last decade, the area under horticulture grew by $2.6 \%$ per annum and annual production increased by $4.8 \%$. During 2017-18, the production of horticulture crops was 311.71 Million Tonnes from an area of 25.43 Million Hectares (Table 1). The production of vegetables has increased from 101.2 Million Tonnes to 184.40 Million Tonnes since 2004-05 to 2017-18 and production of fruits has increased from 50.9 Million Tonnes to 97.35 Million Tonnes since 2004-05 to 2017-18 as illustrated in Figure 1.

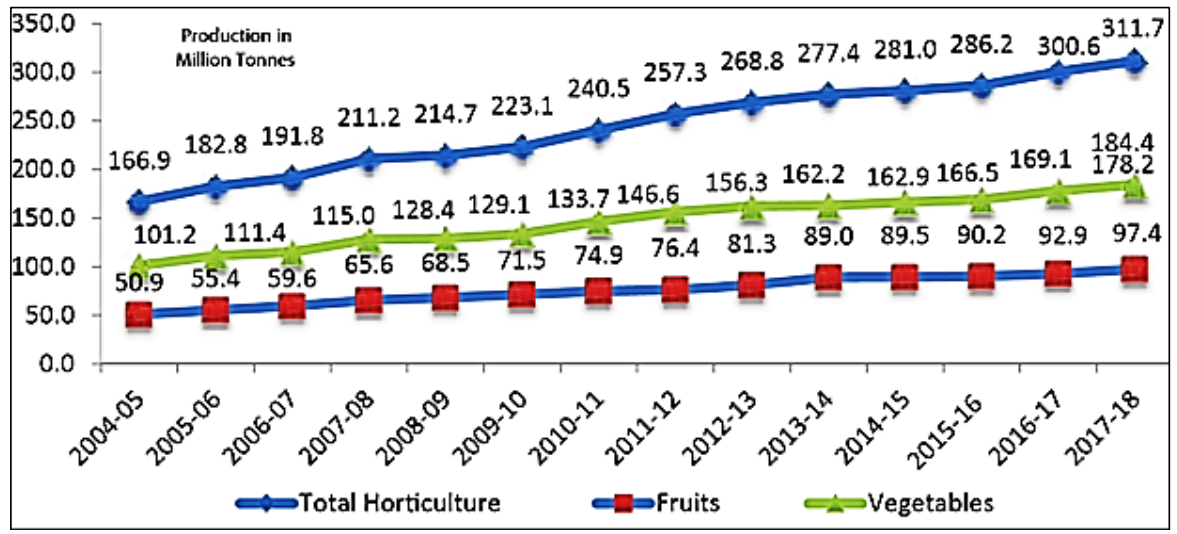

Fig 1: The production of vegetables has increased from 101.2 Million Tonnes to 184.40 Million Tonnes since 2004-05 to 2017-18 and production of fruits has increased from 50.9 Million Tonnes to 97.35 Million Tonnes since 2004-05 to 2017-18

Apart from nutritional remunerations, the production of vegetables advances the economy of a country as these are very good source of earnings and service. The contribution of vegetables remains highest $(59-61 \%)$ in horticulture crop productions over the last five years as shown in Figure 2.

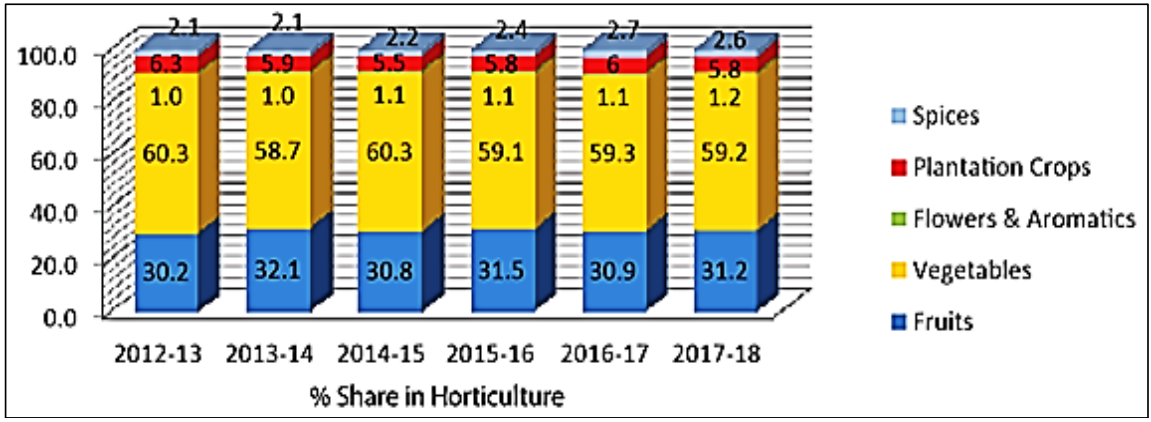

Fig 2: Production share of various horticulture crops 
The total area under fruits was 2.87 Million Hectares with a total production of 28.63 Million Tonnes and productivity of 9.96 MT per hectare during 1991-92, which had increased to 6.5 Million Hectares with a total production of 97.4 Million Tonnes and average productivity of $14.96 \mathrm{MT}$ per hectare by the end of 2017-18. The total area under vegetables was 5.59 Million Hectares with a total production of 58.5 Million Tonnes and average productivity of 10.47 MT per hectare during 1991-92, which has increased to 10.26 Million
Hectares with a total production of 184.40 Million Tonnes with average productivity of 17.97 MT per hectare by the end of 2017-18. There was no flower, medicinal and aromatic plants cultivation in the nation during 1991-92 but covered 1.04 Million Hectares during 2017-18 with a production of 3.65 Million Tonnes and productivity of 3.49 MT per hectare. Area-'000 ha

Production- '000 MT

Productivity-MT/ha

Table 1: All India Area, Production and Productivity of Horticulture Crops over the Years 1991-92 to 2017-18

\begin{tabular}{|c|c|c|c|c|c|c|c|c|c|c|c|c|c|c|c|c|c|c|}
\hline \multirow[t]{2}{*}{ Year } & \multicolumn{3}{|c|}{ Fruits } & \multicolumn{3}{|c|}{ Vegetables } & \multicolumn{3}{|c|}{$\begin{array}{c}\text { Flowers, Aromatic } \\
\text { \&.Medicinal }\end{array}$} & \multicolumn{3}{|c|}{ Plantation Crops } & \multicolumn{3}{|c|}{ Spices } & \multicolumn{3}{|c|}{ Total } \\
\hline & $\mathrm{A}$ & $\mathbf{p}$ & \begin{tabular}{|l|} 
Pdy. \\
\end{tabular} & $\mathbf{A}$ & $\mathbf{P}$ & Pdy. & $\mathbf{A}$ & $\mathbf{P}$ & Pdy. & $\bar{A}$ & $\mathbf{p}$ & Pdy. & $\mathrm{A}$ & $\mathbf{P}$ & Pdy. & $\mathbf{A}$ & $\mathbf{P}$ & Pdy. \\
\hline $1991-92$ & 2874 & 28632 & 9.96 & 5593 & 58532 & 10.47 & & & & 2298 & 7498 & 3.26 & 2005 & 1900 & 0.95 & 12770 & 96562 & 7.56 \\
\hline $2001-02$ & 4010 & 43001 & 10.72 & 6156 & 88622 & 14.40 & 106 & 535 & 5.05 & 2984 & 9697 & 3.25 & 3220 & 3765 & 1.17 & 16592 & 145785 & 8.79 \\
\hline $2002-03$ & 3788 & 45203 & 11.93 & 6092 & 84815 & 13.92 & 70 & 735 & 10.50 & 2984 & 9697 & 3.25 & 3220 & 3765 & 1.17 & 16270 & 144380 & 8.87 \\
\hline 2003.04 & 4661 & 45942 & 9.86 & 6082 & 88334 & 14.52 & 101 & 580 & 5.74 & 3102 & 13161 & 4.24 & 5155 & 5113 & 0.99 & 19208 & 153302 & 7.98 \\
\hline 2004.05 & 5155 & 50988 & 9.89 & 6744 & 101246 & 15.01 & 249 & 818 & 3.29 & 3147 & 9835 & 3.13 & 3150 & 4001 & 1.27 & 18445 & 166939 & 9.05 \\
\hline 2005.06 & 5324 & 55356 & 10.40 & 7213 & 111399 & 15.44 & 391 & 856 & 2.19 & 3283 & 11263 & 3.43 & 2366 & 3205 & 1.57 & 18707 & 182816 & 9.77 \\
\hline 2006.07 & 5554 & 59563 & 10.72 & 7581 & 114993 & 15.17 & 468 & 1058 & 2.26 & 3207 & 12007 & 3.74 & 2448 & 3953 & 1.61 & 19389 & 191813 & 9.89 \\
\hline $2007-08$ & 5857 & 65587 & 11.20 & 7848 & 128449 & 16.37 & 563 & 1264 & 2.25 & 3190 & 11300 & 3.54 & 2617 & 4357 & 1.66 & 20207 & 211235 & 10.45 \\
\hline 2008.09 & 6101 & 68466 & 11.22 & 2981 & 129077 & 16.17 & 597 & 1417 & 2.37 & 3217 & 11336 & 3.52 & 2629 & 4145 & 1.58 & 20662 & 214716 & 10.39 \\
\hline $2009-10$ & 6329 & 71516 & 11.30 & 7985 & 133738 & 16.75 & 692 & 1593 & 2.30 & 3265 & 11928 & 3.65 & 2464 & 4016 & 1.63 & 20876 & 223089 & 10.69 \\
\hline $2010 \cdot 11$ & 6383 & 74878 & 11.73 & 8495 & 146554 & 17.25 & 201 & 1636 & 2.33 & 3306 & 12007 & 3.63 & 29.40 & 5350 & 1.82 & 21825 & 240531 & 11.02 \\
\hline $2011-12$ & 6705 & 76424 & 11.40 & 8989 & 156325 & 17.39 & 760 & 2218 & 2.92 & 3577 & 16359 & 4.57 & 3212 & 5951 & 1.85 & 23243 & 257277 & 11.07 \\
\hline $2012-13$ & 6982 & 81285 & 11.64 & 9205 & 162187 & 17.62 & 790 & 2647 & 3.35 & 3641 & 16985 & 4.66 & 3076 & 5744 & 1.87 & 23694 & 268848 & 11.35 \\
\hline $2013 \cdot 14$ & 7216 & 88977 & 12.33 & 9396 & 162897 & 17.34 & 748 & 3192 & 4.27 & 3675 & 16301 & 4.44 & 3163 & 5908 & 1.87 & 24198 & 277352 & 11.46 \\
\hline $2014-15$ & 6110 & 86602 & 14.17 & 9542 & 169478 & 17.76 & 908 & 3143 & 3.46 & 3534 & 15575 & 4.41 & 3317 & 6108 & 1.84 & 23410 & 280986 & 12.00 \\
\hline $2015 \cdot 16$ & 6301 & 90183 & 14.31 & 10106 & 169064 & 16.73 & 912 & 3206 & 3.52 & 3680 & 16658 & 4.53 & 3474 & 6988 & 2.01 & 24472 & 286188 & 11.69 \\
\hline $2016-17$ & 6373 & 92918 & 14.58 & 10238 & 178172 & 17.40 & 970 & 3364 & 3.47 & 3598 & 17972 & 4.99 & 3671 & 8122 & 2.21 & 24851 & 300643 & 12.10 \\
\hline $2017-18$ & 6506 & 97358 & 14.96 & 10259 & 184394 & 17.97 & 1044 & 3651 & 3.49 & 3744 & 18082 & 4.83 & 3878 & 8124 & 2.09 & 25431 & 311714 & 12.25 \\
\hline
\end{tabular}

Need for diversification towards horticulture in Haryana Ideal agro-climatic conditions give great chance to the advancement of horticultural crops in Haryana. Different focal points affixed to broadening from conventional crops to horticulture crops make it great possibility for farmers of state. For instance, higher biomass productivity of horticultural crops than open field crops brings about viable consumption of natural resources, more yield per drop, value addition potential outcomes further the prospects of high value crops, remunerative nature of horticulture crops can help to improve income level, nutrition status and create employment opportunities for the farmers. Besides this, export potential of many horticultural crops proves helpful to a country to earn foreign exchange and reduce current account deficit. Due to these advantages of the horticulture sector Indian government has always supported the diversification from traditional crops to horticulture crops throughout India including Haryana. Government's endeavors have come about into extensive progress in development of area under horticulture crops.

\section{Study area}

Haryana state is situated between $27^{\circ} 39^{\prime}$ to $30^{\circ} 56^{\prime}$ North latitude and $74^{\circ} 27^{\prime}$ to $77^{\circ} 36^{\prime}$ East longitude and comprises 22 districts.

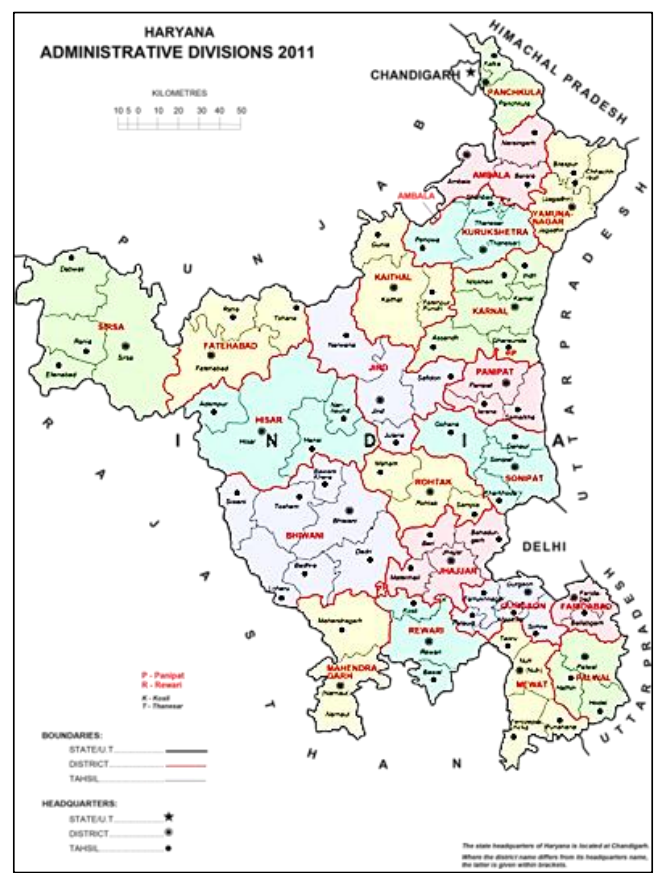

Fig 3: Map of Haryana 


\section{Fruits}

Total area under fruit cultivation in Haryana was 64 thousand ha along with production of 793.4 MT by the end of 2017-18. Among different districts, Sirsa district occupies the largest area, around 10.3 thousand ha with 221.2 MT productions of citrus. Among all the fruit crops, Citrus was acquainted with maximum area (20.8 thousand ha) and production (335.8 MT) in the state in the year 2017-18.

\section{Vegetables}

Haryana state being in close by vicinity of Delhi is preferably suited for vegetable cultivation. During the year 2017-18, the area under vegetables was 446.9 thousand ha with the production of 7140.7 MT. Cauliflower covered the largest area comprising of 39.9 thousand ha with production of 698.9 MT followed by tomato and potato. Among different districts, Sonipat district enclosed the largest area, around 50.2 thousand ha with 901.2 MT production.

In spite of the fact that vegetable development is not secured under NHM programmes, in any case, to help the exercises of vegetable in the State, different components of NHM like IPM, protected cultivation and vegetable seed production were incorporated to build the production and productivity of the vegetables. Being proximity to NCR, the prerequisite of fresh vegetables has expanded manifold. The Department is currently concentrating on introduction of latest technologies in a joint effort with Israel Government. A Center of Excellence for Vegetables Indo-Israel Agriculture Project was established in Karnal, Haryana.

\section{Flowers}

Cultivation of flowers amongst the farmers has become a remunerative venture, as there is a good demand in the national and international markets. During the year 2017-18, the area under flowers was 5.5 thousand ha with the production of 57.6 MT of loose flowers and 4.5 MT of cut flowers in the state.

\section{Spices}

The scenario of area, production and productivity of spices in Haryana was contrary to that of vegetables and fruits. The share of Haryana's area under spices at all India level was as low as 0.44 percent but share of production was around two times which was mainly due to the higher productivity $(4.55$ MT/ha) against all India average of 2.09 MT/ha during 201718 (Saxena, 2018) ${ }^{[24]}$. Yamuna Nagar secured first place among different districts in terms of the area and production of spices in the state.

\section{Protected Cultivation}

Protected cultivation/green-house/low poly tunnels production techniques are now available for growing cut-flowers and vegetables along with offseason production. Crops like tomato, cucurbits, cabbage, cauliflower, cucumber, lettuce, onion, spinach, brinjal, pepper, turnip, radish, rose, chrysanthemum, gerbera and carnation can be successfully grown for high quality under protected cultivation. Highvalue cash crops, vegetables, and flowers are successfully grown and managed under controlled environmental conditions in protected cultivation with greater per unit productivity and profitability (Choudhary 2016) ${ }^{[7]}$. According to Ghanghas et al. (2018) ${ }^{[12]}$, protected cultivation involves the exhaustive use of inputs such as soil, water, fertilizers, pesticides and power which leads to amplified production and productivity per unit of land, water, energy and labour along with fresh produce of superior quality, high fertilizer and water use efficiency, establishment of high-cost infrastructure with provision of subsidy and round the year employment generation to the poly house farmers.

Kumar et al. (2018) ${ }^{[17]}$ collected the data from all District Horticulture offices and Department of Horticulture and found that the total number of poly houses was 1356 in Haryana during the year 2014-15. Out of 1356, there were 5 Hi-Tech Poly houses (HTPH), 1010 Natural Ventilated Poly houses (NVPH), 267 Net Houses (NH) and 74 Walk in Tunnels (WIT). The maximum number of poly houses was observed in Karnal (220) district followed by Sonepat (183), Rohtak (156), Bhiwani (97), Hisar (84) and Panipat (83), while the minimum number of poly houses was found in Mahendergarh (10) district of Haryana. The total number of poly houses increased from 1356 to 1589 in the year 2017-18 and the maximum number of poly houses was adopted in Sonepat followed by Karnal, Bhiwani and Rohtak while the minimum number of poly houses was found in the district Mahendergarh. Different protected technologies exhibited greater net return and $\mathrm{B}$ : $\mathrm{C}$ in poly house while it was lowest in open field condition (Singh et al., 2011) ${ }^{[26]}$. Polyhouse farming can assist the farmer in income generation round the year by growing multiple crops and fetching finest pricing for off-season produce (Kumar et al., 2017) ${ }^{[16]}$.

Earnest efforts are being done by the government to encourage protected cultivation to guarantee sustainable food and nutritional safety to each Indian resident and enrichment of farming community income (Mishra et al., 2010) ${ }^{[20] .}$ However, promotion and development of protected cultivation is not up to the mark, in spite of the support and endorsement by Haryana government to exploit larger production as well marketing potential in the state. Furthermore, there are several constraints and problems which restrict protected cultivation of vegetables (Sirohi et al., 2002) [28]

\section{Constraints in Horticulture Production under Poly House}

The major problems faced by the farmers in the production of vegetable under poly house were studied by (Kumar et al., 2018) ${ }^{[17]}$. The major constraint in poly house cultivation was short life span of polyethylene sheet as it easily got damaged with high wind flow. In addition to this, infestation of nematode and whitefly was another important constraint because they damage the plants and reduce the production (Sharma et al., 2009) ${ }^{[25]}$. High cost of fertilizer and high cost of seed were also accounts as major constraints because in poly house, specific variety of seed/seedling is being grown. Lack of availability and high price of poly house material were also key constraints because low cost alternate material is not available and is limited. Lack of knowledge of latest package of practices was another constraint in poly house production (Samantaray et al., 2009) ${ }^{[23]}$. Weeds generate the competition for nutrient and space and retard the development of vegetable seedlings in poly house, hence it can be considered as a constraint in poly house crop growing. High cost of skilled labour, lack of availability of fertilizer on appropriate time, high weather fluctuations and fear of failure of technology were also important constraints in poly house production. Superior initial investment, lack of technical guidance and the high cost of pesticides and fertilizers were the main production associated troubles faced by the respondent farmers (Malik, 2017) ${ }^{[19]}$. 


\section{Constraints in Marketing of Poly House Produce}

Kumar et al., $2018^{[17]}$ found that lack of minimum support price (MSP) was the chief and foremost marketing problem of the vegetable growers because there is no fixed MSP for the vegetables. In addition, high price fluctuation accounts as a main constraint because of low price at the time of seasonal glut. Inadequate market information and high cost and lack of transportation facility were another big problems faced by farmers. Malpractices in weighing, inadequate availability of quality packing material at genuine price and unavailability of proper market place were the important marketing constraints. As far as marketing efficiency was concerned, producerconsumer channel was adjudged as most proficient among all other marketing channels (Bhatia et al., 2017) ${ }^{[6]}$. Wadkar et al. (2006) ${ }^{[30]}$ observed that profitability of cut-flowers under poly house conditions was found the utmost in orchid and least in rose.

\section{Reasons for Discontinuation of Poly House}

Regardless of the genuine efforts made by government, farmers are discontinuing to put into practice which is shown by the results that around $75 \%$ of ongoing poly house farmers were found susceptible to discontinuity. Most significant reasons for discontinuation were socio-economic factors such as lack of ability to uphold the construction owing to high cost of cladding material for maintenance, larger dependency on outside support schemes for raising of funds, trivial wealth returns being capital exhaustive venture and deficiency of remunerative price guidelines by the government for the produce followed by technological factors such as shortage of field functionaries expertise of public extension system in horticulture, lack of comprehensive knowledge of subjects like horticulture, growing media, plant physiology, plant protection along with proper engineering credentials of farmers to make available an atmosphere best suited for the growth of plant and dearth of detailed knowledge of greenhouse designing particularly gutter height requirement for different crops and arrangements of environment control followed by the lack of knowledge of horticulture processing and value addition (Ghanghas, 2019) ${ }^{[11]}$.

\section{Post-harvest management}

Post-harvest technology might be characterized as the part of agriculture that manages with all the operations directly from harvesting or even the pre harvest stages till the commodity arrives the customer, either in fresh (grains, apple, mango, tomato fruits) or processed form (flour, juice, nectar, ketchup) and usage of the wastes (pomace, peel, seed, skin etc.) in a beneficial way (assembling of fermented drinks, colour extraction, pectin extraction and so on). Horticultural produce are of transient nature which brings about misfortunes in amount and nature of produce among harvesting and their utilization. The extent of postharvest losses in fresh fruits and vegetables is evaluated at $5-25 \%$ in developed nations and 25 $50 \%$ in developing nations. In India, fruits and vegetables are quickest developing segments inside agribusiness, expected losses extend up to $40 \%$ contingent on the item. With the scientific progression in horticulture, per unit decrease of post- harvest losses is less expensive than comparable increment underway of high value horticultural crops. Accordingly, formation of post-harvest infrastructure and awareness need most extreme regard for increment the accessibility of quality nourishments. To lessen these losses, producers and handlers like wholesalers, specialists, sub wholesalers and retailers must comprehend biological and ecological variables engaged with deterioration and utilization of post-harvest technology to limit these losses so most ideal quality could be kept up.

\section{Post-harvest Losses}

At present, the post-harvest losses are around 20-30\% in various horticultural crops (Table 2). This is going on for the most part because of disparity between the production and infrastructure advancement for Post-harvest management. Innovation advancement has been in vogue yet its selection is far underneath. Post-harvest management comprising precooling, passive evaporative cooling for expanding the life span of usability of fresh and processed fruits, vegetables and floriculture products have been standardized. Packaging materials like Corrugated Fiberboard boxes (CFBs), perforated punnettes, cling films, sachets, wraps and so forth have been standardized for fresh horticultural commodity. Tetra packs of various items are currently house-hold things. Proper produce dealing during the post-harvest chain depends on understanding the elements that influence the quality and security of the item and the various components to limit their effect. Straightforward taking care of practices can have desired effect on article quality and safety like appropriate harvesting time, maintaining a strategic distance from direct daylight, proper dealing, appropriate ventilation, etc.

Bottlenecks in cold storage and processing industry including during transportation are non-efficient stockpiling/warehousing, processing and marketing techniques, non-appropriation of productive innovations, high power duty, low region under irrigation, high capital expense on packaging material and insufficient institutional finance at low rates, high insurance premium in risk inclusion, farm connectivity by road yet to be taken off. Inputs delivery is not on schedule, innumerable varieties, poor acquisition and coordination, absence of modest and promising credit, infrastructural limitations and larger middle people apply antagonistic pressure on farmer edge and break down quality because of various dealing with. 
Table 2: Harvest and Post-Harvest Losses of Major Horticultural Crops

\begin{tabular}{|l|l|l|l|}
\hline Sr. No & Name of Crops & $\begin{array}{c}\text { \% Average Loss (CIPHET } \\
\text { Nanda etal 2012) }\end{array}$ & $\begin{array}{l}\text { \% Average Loss (CIPHET } \\
\text { Jha etal 2015) }\end{array}$ \\
\hline 1. & Apple & 12.3 & 10.39 \\
2. & Banana & 6.6 & 7.76 \\
3. & Citrus & 6.4 & 9.69 \\
4. & Grapes & 8.3 & 8.63 \\
5. & Guava & 18.01 & 15.88 \\
6. & Mango & 12.7 & 9.16 \\
7. & Papaya & 7.36 & 6.70 \\
8. & Sapota & 5.8 & 9.73 \\
9. & Onion & 7.5 & 8.20 \\
10. & Tomato & 13.0 & 12.41 \\
11. & Cabbage & 6.9 & 9.37 \\
12. & Cauliflower & 6.9 & 9.56 \\
13. & Green Pea & 10.3 & 7.45 \\
14. & Potato & 9.0 & 7.32 \\
15. & 'lapioca & 9.8 & 4.58 \\
\hline
\end{tabular}

\section{Source: CIPHET Report}

\section{Causes of Post-Harvest losses}

Fresh horticultural crops are varied in morphological structure (roots, stems, leaves, flowers and fruit) organization and in common physiology. In this way, product necessities and proposals for most extreme post-harvest life may shift with commodities. All fresh horticultural produce are high in water content and thus are prone to desiccation (wilting and drying up) and to mechanical damage. These are additionally defenseless to attack by microbes and fungi, with the outcome of pathological breakdown of the produce. Both biological and ecological factors are associated with decay of plant produce. It would, in this way be alluring to comprehend these elements first. It would, in this way be necessary to comprehend these components first.

Mechanical damage is a significant reason for losses. A large number of these wounds cannot be seen at the time that the item is packed and transported, for example, bruising in apples, banana, citrus and so forth however expression of which show up at a lot later stage. Different sources of loss incorporate over maturing, senescence, the development of pathogens and the advancement of inert contamination. Physical misfortune can likewise emerge from dissipation of intercellular water, which prompts an immediate reduction in weight. The subsequent monetary loss is fundamentally because of the reduced mass of produce that remains available for sale however can likewise be because of an entire bunch of product being dismissed on account of a little extent of wasted things in the cluster. Loss of quality is the second reason for post-harvest loss, and this can be because of physiological and compositional changes that modify the appearance, taste and surface and make produce less tastefully attractive to end clients. The changes may emerge from normal metabolism of produce (for example senescence) or abnormal occasions (for instance chilling injury) emerging from the post-harvest condition. Economic loss is brought about on the grounds that such produce will get a lower cost. In numerous business sectors there is no interest for below average produce, even at marked down value, which prompts all out economic loss despite the fact that the products may at present be consumable.

Physiological disorders can result from factors like very high and low temperatures, relative humidity and so forth. High temperature conditions are likewise harmful to perishable crops prompting confined bleaching, necrosis (sunburn or sunscald) or general breakdown. RH can impact water loss, decay improvement, the occurrence of some physiological disorders, and consistency of fruit aging. Extreme water stress brings about expanded burn from the sun of fruits, unpredictable maturing of pears, intense and rough surface in peaches, and fragmented kernel advancement in nuts. Moderate water stress diminishes produce size and results in increment of soluble solids content, acidity, and ascorbic acid content. On the other hand, overabundance water supply to plants brings about splitting of fruits (for example, cherries, plums, and tomatoes), unnecessary turgidity leading to augmented susceptibility to physical harm, (for example, oil spotting on citrus fruits), decreased firmness, delayed development, and diminished soluble solids content. Freezing for the most part brings about quick breakdown of their tissues and an all-out loss of cellular integrity of perishable products. Chilling injury is showed in a variety of symptoms including surface and internal discoloration, pitting, water soaking, failure to ripen, uneven ripening and advancement of off flavors. Fresh produce can turn out to be microbiologically contaminated at any point along the farm-to table food chain. The Central Warehousing Cold Chain Pvt. Ltd. (CWCCL) has declared the dispatch of the nation's first ever controlled atmosphere storage facility and Food Park. There are some other government and private food processing ventures coming up. Four food parks are planned in the districts of Sirsa, Jind, Sonepat and Ambala and government is investing in them. Fruits and vegetables are highly perishable due to high water content so the government has proposed 21 pack houses and 9 cold stores. Israeli agricultural scientists are imparting training and providing seeds to farmers in Haryana to grow vegetables throughout the year even in the water scarcity condition as the climatic environment in Haryana and Israel are alike. Up to date technologies for food processing and storage are crucial for minimizing the post-harvest losses and maximizing the profitability of farmers. 


\section{Agro processing}

Just after the commencement of green revolution and accomplishment of self-adequacy in food production, the need for food processing was realized. It is approximated that 30$35 \%$ of fruits and vegetables of about Rs. 23,000 crores worth get waste due to unavailability of sufficient processing industries to process the perishable fruits and vegetables at the time of glut in the market, thus depriving the produce and economy of the farmer. Roughly about $2 \%$ of the total fruits and vegetables production are processed in India against $40 \%$ in some developing and 70-80\% in other developed nations. Agro processing plays an important role particularly in a state like Haryana where agriculture production has already reached plateau and is stagnant. Kumar et al. (2016) studied the importance of agro industries in rural areas where employment opportunities are diminishing. He stated that traditional processing of village oil ghani and jaggery and khandsari were not synchronized with time whereas cereal and pulses along with fruits preservation and processing industries are gaining popularity in recent time which leads to growth and adoption of proper post-harvest technology chiefly for pulse milling, oil extraction and jaggery recovery. The expansion of village level processing was slowed down by different factors for instance land acquisition complexity and increased prices, inadequate investment for small entrepreneurs, lack of awareness and knowledge of skills, higher cost of machinery and poor support on marketing and policy front. Consequently, an inclusive plan is required to help up agro processing in the state, which involves the physical, functional and market framework progress alongside provision of single window system, tax return and need of improvement for export subsidies.

Moving further, accessible sources propose that agroprocessing not only help in taking care of the issue of seasonal unemployment, food and nutritional security, relocation of individuals from rural to urban zones, postharvest losses, yet additionally upgrades consumer satisfaction, up gradation in quality and expanding time span of usability, income and employment generation through value addition of farm commodities (Bharti et al., 2003; Dixit et al. 2010) ${ }^{[5,10]}$. In addition, agro processing centres were discovered monetarily practical venture and helped aided in keeping away from trouble deal simultaneously build forward and backward linkages (Srinivas et al., 2009; Dixit et al. 2011) ${ }^{[29,9]}$ along with realistic impact at both individual and society level (Oladipo, 2008) ${ }^{[21]}$.

Status and growth of agro processing industry in Haryana The level and degree of processing is the function of accessible innovation and foundation. Despite the fact that request of processed items and supply of raw material contributing towards the development of agro processing. Kumar et al. (2016) presented the annual compound growth rate of production of various crop specific processing industries in Haryana over different decades since 1980s in Table 3 . The processing of cereals and pulses at village level enterprises expanded at a yearly compound development pace of $2.54 \%$ during 1980-81 to 1989-90, while, the development decelerated during 1990-91 to 2000-01. Compound growth rate $(\%)$ of fruit preservation and processing industry increased continuously over different decades.

Table 3: Growth of agro processing industries in Haryana

\begin{tabular}{|c|c|c|c|}
\hline \multirow{3}{*}{ Particulars } & \multicolumn{3}{|c|}{ Compound growth rate (per cent) } \\
\hline & Period-1 & Period-11 & Period -III \\
\hline & $\begin{array}{c}1980-81 \text { to } \\
89-90\end{array}$ & $\begin{array}{c}1990-91 \text { to } \\
2000-01\end{array}$ & $\begin{array}{c}2001-02 \text { to } \\
2010-11\end{array}$ \\
\hline $\begin{array}{l}\text { Processing of } \\
\text { cereals and } \\
\text { pulses industry }\end{array}$ & 2.54 & -3.36 & 5.80 \\
\hline $\begin{array}{l}\text { Village oil ghani } \\
\text { industry }\end{array}$ & -12.71 & -8.71 & 24.71 \\
\hline $\begin{array}{l}\text { Jaggery- } \\
\text { khandsari } \\
\text { industry }\end{array}$ & -10.22 & -2.49 & 4.38 \\
\hline $\begin{array}{c}\text { Fruit } \\
\text { preservation and } \\
\text { d processing } \\
\text { industry }\end{array}$ & 6.28 & 11.34 & 2.32 \\
\hline
\end{tabular}

The likely purpose behind negative development during nineties might be

1. Short supply of pulses during nineties which was substituted by the import.

2. Investment in food grain and oilseeds division industries by private players at medium and large scale under advancement and globalization which repressed the development of small scale/cabin industry in provincial catchments. It merits referencing that there is quantum hop in production of food grains over a period with the intervention of high yielding varieties of pulses and all the more especially low water prerequisite of paddy varieties.
This stock side circumstance does not completely clarify a yearly development of 5.80\% during the period of 2001-02 to 2010-11. Here, the credit likewise goes to post-harvest advances appropriate for small and medium business visionaries. For example, part of progress in the recuperation of dal (up to $25 \%$ ) over ordinary burr factory has been seen when handled through improved dal plant, for example, PKV Mini Dal Mill (created under All India Coordinated Research Project on Post-Harvest Engineering and Technology (AICRP on PHET), PDKV Akola centre), CIAE dal Mill (manufactured by ICAR-CIAE Bhopal), IIPR Mini Dal Mill (created by ICAR-IIPR Kanpur). The negative development of rural level oil ghani enterprises for successive two decades 
is actually an issue to review and stand out for us towards advances of generation and processing too. The disappointment of oil ghani industries (signify oil extraction through conventional kohlu system) was by virtue of lower recovery of oil. Likewise, jaggery and khandsari manufacturing in Haryana was on the edge of nearer toward the finish of 2001 mostly in view of two reasons that are

1. Moving sugarcane region under rice-wheat cropping system.

2. Surplus of marketable sugarcane occupied to Cooperative Sugar Mills. Joshi et al. (2006) ${ }^{[15]}$ has analyzed "Sources of Agricultural Growth in India: Role of Diversification towards High-value Crops" in their research. The scientists uncovered that the innovative up gradation was the significant factor in 1980's while rising costs and expansion towards high-esteem crops were the prevailing sources of development during 1990s.

In spite of the fact that Haryana is not a leading state in fruit production however fruit preservation as achar and chitin has been practiced since ages. The development of this division is certain. It merits referencing that the handling of horticulture produce is presently taking development in light of government scheme and incentives. For example, interest free credit up to $75 \%$ of the duty paid on the sale of commodities produced in such industrial units is given under the Haryana Value Added Tax Act, 2003 for a time of 5 years from the date of beginning of commercial production. The new machines created for preparing like pomegranate aril extractor, vegetable washer, carrot washer, aonla and kinnow juicer, heat pump dryer, tomato grader might be advanced with $50 \%$ subsidy. In addition to this, new industrial units established in the State are excluded from payment of power duty for a time of 5 years from the date of commercial production, no market expense is charged on the produce developed in the state and even utilized fruits and vegetables as raw material by food processing ventures.

\section{Factors influencing the pace of development of agro- processing industries in Haryana}

It is clearly evident that land esteem is higher in Haryana, as state is in vicinity NCR and Delhi, capital of the nation. Lacking fund, higher charges of raw material, uneven supply and market competition were evaluated as three most significant limitations. In any case, absence of technical know-how, higher pace of interest, shortage of electricity and higher charge per unit were considered among top constraints ruining the pace of agro industrialization in the state (Rai. et al., 2012) ${ }^{[22]}$. Different issues experienced in processing were deficiency of energy and under use of introduced capacity, increasing rate of power charges and fuels and absence of specialized labor (Grover et al., 1996) ${ }^{[13]}$. Thus, a few issues looked in marketing of final results is enrolled as absence of marketing cooperatives, lack of proficient and less expensive transport, range of taxes further confine the development of agro businesses (Jairath, 1996) ${ }^{[14]}$. As indicative measures, Government of Haryana may facilitate the technique for land acquisition for post-harvest activities, as these are corresponding to agriculture. Here, R\&D associations, for example, Indian Council of Agricultural Research (ICAR) supported AICRP on PHET centre and Haryana Agricultural University can play a front role in development of area specific devices, implements, apparatus and procedure protocols and their commercialization through enterprise advancement program.

\section{Conclusion}

In this review paper, we deal with the special problems in relation to horticultural crops in Haryana. We represented the horticulture scenario of India and Haryana. Agriculture sector plays a noteworthy role in the economy of Haryana as it is predominantly an agrarian economy. Horticultural crops covers around $8.17 \%$ of the cropped area. Favorable agroclimatic conditions give great chance to the development of horticultural crops in Haryana. There is a need for diversification towards horticulture in Haryana. Protected cultivation is extremely useful to give the ideal condition that horticulture cultivation is needed. There are several constraints and problems which limit protected cultivation of horticultural crops. In Haryana, post-harvest losses are 3-18 percent, only $2 \%$ of fruits and vegetables processing is done. Through processing the value of the commodities can be increased by converting it to various products by utilizing conventional or modern processing techniques, thereby the storage life of the produce is upgraded. Simple proper handling practices can have desired impact on product quality and safety. The accessibility of framework facilities can be the spine for agrarian development particularly for fruits and vegetables. Some fruits and vegetables are for instant use as they are perishable in nature, so cannot be stored without the facility of cold storage resulting loss of $20-30 \%$ of their crops at various levels of marketing. This is the main reason for small and marginal farmers because of which they are not in a condition to confront these difficulties and to move towards horticulture production. Utilization of micro irrigation techniques etc. will check deterioration or wastage by building up pre-cooling centers in specific commodity production areas, using high yielding hybrid genotypes, deputing exceptionally experienced and technically trained manpower, ensuring proper grading, packing, transportation and marketing. To keep pace with improved production and productivity, various machines have been developed for effective cultivation, intercultural operations, harvesting, grading, packaging and value-addition.

\section{References}

1. Anonymous. Fertiliser Statistics. The Fertiliser Association of India, New Delhi, 2014.

2. Anonymous. Economic survey of Haryana, 2014-15.

3. Anonymous. Haryana state agriculture policies, Government of Haryana, 2017.

4. Anonymous. Agriculture Census 2015-16. All India Report on Number and Area of Operational Holdings. Agriculture Census Division, Department of Agriculture and Cooperation, Ministry of Agriculture, Govt. of India, 2018.

5. Bharti DK, Gangwar LS, Kumar S. Growth of food processing industry in India. Indian Journal of Agricultural Economics. 2003; 58(3):614.

6. Bhatia JK, Bishnoi DK, Kumar N. Protected cultivation of tomato in Haryana. Indian Journal of Economics and Development. 2017; 13(2a):397-400.

7. Choudhary AK. Scaling-up of protected cultivation in Himachal Pradesh, India. Current Science. 2016; 111(2):272-277.

8. Devgan K, Kaur P, Kumar N, Kaur A. Active modified atmosphere packaging of yellow bell pepper for retention of physico-chemical quality attributes. Journal of food science and technology. 2019; 56(2):878-888.

9. Dixit AK, Nanda SK, Singh KP, Kudos SKA. Economic benefits of Vivek millet thresher-cum-pearler and agro 
processing centre in hilly region of Uttarakhand. Journal of Hill Agriculture. 2011; 2(2):177-182.

10. Dixit AK, Sharma PC, Nanda SK, Kudos SKA. Impact of processing technology in hilly region: A study on extraction of apricot kernel oil. Agricultural Economics Research Review. 2010; 23:405-410.

11. Ghanghas BS. Reasons for Discontinuation of Polyhouse Cultivation by Farmers in Haryana. Journal of Community Mobilization and Sustainable Development. 2019; 14(1):121-126.

12. Ghanghas BS, Malik JS, Yadav VPS. Sustainable vegetables and flowers production technology (Poly House): Problems and Prospects in Haryana. Indian Research Journal of Extension Education. 2018; 18(2):12-16.

13. Grover RK, Suhag KS, Aneja DR. Retrospects and prospects of agro-processing industries in Haryana. Indian Journal of Agricultural Marketing. 1996; 10(2):1017.

14. Jairath MS. Agro processing and infrastructure development in Hilly area: A case of fruit and vegetable processing. Indian Journal of Agricultural Marketing. 1996; 10(2):28-47.

15. Joshi PK, Birthal PS, Nicholas M. Sources of Agricultural Growth in India: Role of Diversification towards High-Value Crops, MTID Discussion Paper No. 98, International Food Policy Research Institute, 2006, 136.

16. Kumar P, Chauhan RS, Grover RK. An economic analysis of cucumber (Cucumis sativus L.) cultivation in eastern zone of Haryana (India) under poly house and open field condition. Journal of Applied and Natural Science. 2017; 9(1):402-405.

17. Kumar P, Chauhan RS, Tanwar N, Grover RK. Status and constraints in vegetable cultivation under polyhouse in Haryana. Advances in Bioresearch. 2018; 9(2):61-66.

18. Kumar S, Akshu. Importance and Scope of Horticultural Development in Haryana- some issue and challenges. International Journal of Research in Economics and Social Sciences. 2018; 8(1):494-505.

19. Malik K. Economic viability of cucumber cultivation in greenhouses. International Journal for Innovative Research in Multidisciplinary Field. 2017; 3(6):366-368.

20. Mishra GP, Singh N, Kumar H, Singh SB. Protected Cultivation for Food and Nutritional Security at Ladakh. Defence Science Journal. 2010; 61(2):219-225.

21. Oladipo JA. Agro Industry as a strategy for development: An impact assessment of Nigeria oil palm industry. European Journal of Social Sciences. 2008; 7(1):75-87.

22. Rai A, Gandhi S, Kumar N, Sharma DK, Garg MK. Ergonomic intervention in aonla pricking operation during preserve preparation in food processing industries. Work, 41(Supplement 1), 2012, 401-405.

23. Samantaray SK, Prusty S, Raj RK. Constraints in vegetable Production- Experiences of tribal vegetable growers. Indian Research Journal of Extension Education. 2009; 9(3):32-34.

24. Saxena. Horticultural Statistics at a Glance, 2018. www.agricoop.nic.in.

25. Sharma HK, Pankaj, Singh B. Protected Cultivation and Nematode Problem. Indian Journal of Nematology. 2009; 39(1):1-8.

26. Singh AK, Singh B, Gupta R. Performance of sweet pepper (Capsicum annum) varieties and economics under protected and open field conditions in Uttarakhand.
Indian Journal of Agricultural Sciences. 2011; 81(10):973-975.

27. Singh VP, Singh RP, Godara AK, Malik TP, Arora SK, Mehra R. Performance of Capsicum cultivars under naturally ventilated polyhouse environment. Haryana Journal of Horticultural Sciences. 2007; 36(3/4):307.

28. Sirohi NPS, Neubauer E, Singh B. Growing vegetables under protected conditions. In proceedings: International Conference on Vegetables, Bangalore, India, 2002, 20712.

29. Srinivas K, Singh KP, Kumar A, Bisht KKS. Rural entrepreneurship development for generating income and employment-a case study of agro processing centre in Almora district. Journal of Agricultural Development and Policy. 2009; 19(1):44-53.

30. Wadkar SS, Bagade SR, Veerkar PD. A study on the economics of cut flower production under polyhouse. Agricultural Economics Research Review. 2006; 19:214. 